\title{
The Well at Musov - Technical and Technological Aspects of the Construction Project Dating TO THE BeginNing of THE COMMON ERA
}

\author{
Radka KNAPEK ${ }^{1}$, Ondrej SEDO ${ }^{2}$ \\ ${ }^{1}$ Institute of Archaeology of the Czech Academy of Science, \\ Cechynska 363/19, 60200 Brno, Czech Republic \\ ${ }^{2}$ Institute of Archaeology of the Czech Academy of Science, \\ Cechynska 363/19, 60200 Brno, Czech Republic \\ radka.knapek@gmail.com, ondrej.sedo@post.cz
}

DOI: $10.31490 /$ tces-2018-0007

\begin{abstract}
Archaeological excavation at the site Musov - Neurissen conducted between 1993 and 1994 revealed a well belonging to the building with the apse. Both archaeological features were part of the Roman military camp from the Augustan era. The well remained unfinished,however its dimensions (10 x 10 Roman feet (2.96 $\times 2.96 \mathrm{~m})$ and expected depth of up to approximately $16 \mathrm{~m}$ ) suggest that this location was chosen intentionally for a realisation of a demanding construction project.
\end{abstract}

\section{Keywords}

Moravia, Musov, Augustan era, Roman military architecture, military baths, well.

\section{Introduction}

During the archaeological rescue excavation carried out by the Institute of Archaeological Heritage Brno, between the years 1993 and 1994, a well,dating to the Roman era,situated in the area of a terrace with a local name of "Neurissen" in Musov (cadastre Musov, village Pasohlavky, district Brno - venkov, region Moravia, Czech Republic; Fig. 1 was excavated.

Excavated part of the camp of the Augustan era (marked as Musov - Neurissen I) was situated in the area of a terrace at the edge of heights with a hill top called Burgstall. The hilltop itself was used by the Roman armies during the Augustan era, and subsequently during military engagements of the Marcoman-

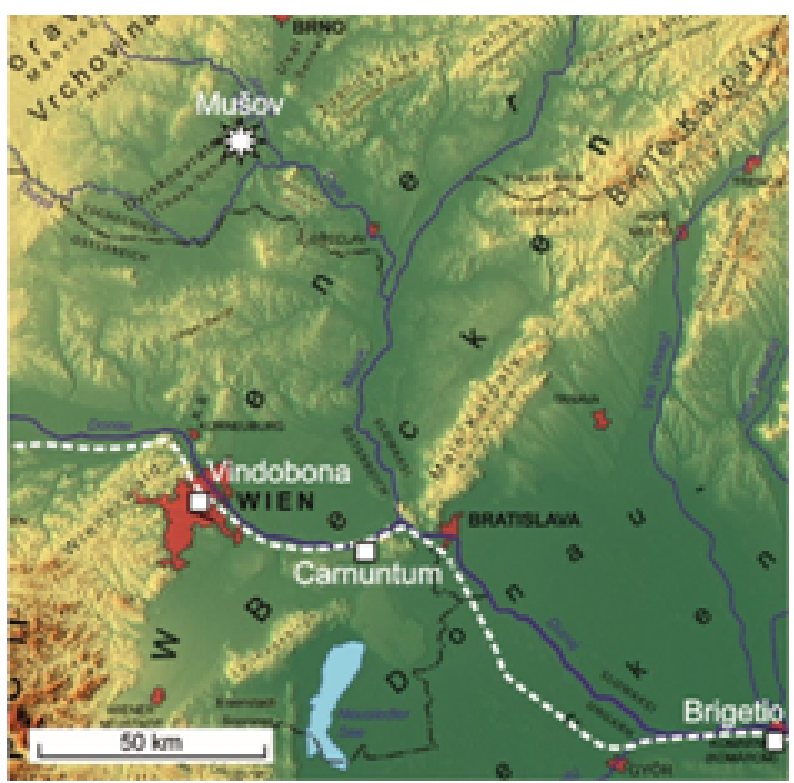

Fig. 1: Musov location in the area of southern Moravia; white coloured line - Roman frontier on the middle Danube river and the legionary camps 11 


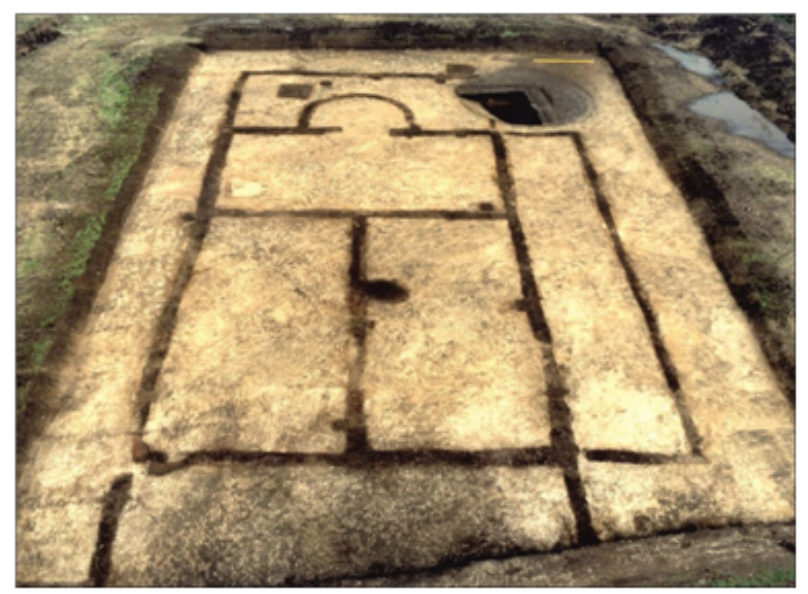

Fig. 2: The building with the apse and circular shape in the place where the wellhead can be observed. (The length of a yellow rod placed in the excavated area is $4 \mathrm{~m}$.)

nic Wars. The site is located $90 \mathrm{~km}$ north of the northern borders of Roman territories on the river Danube.

\section{The Well at Musov}

The well was found in a near vicinity to the building with the apse (fig. 2), and belonged to the housing complex of the Roman camp labelled as Muaov - Neurissen I. This complex can be dated to the period of early empire and it is most likely associated with the expedition led by Tiberius against the Marcomannic king Marobuduus in the year AD 6. We present this interpretation despite the fact that the Roman presence in Musov prior the Marcomannic Wars is still being seen as problematic and is often questioned in the academic circles [7, [9], 10, see also [5]. (Dating of the relevant activities associated with the primary camp to the older period is, however,highly likely.)

A winter camp for the Roman army (hiberna) was built at Mušov.Its builders used wood and clay for the construction of the fortifications and the erection of the buildings on the site. Nevertheless, the decisive parts of the camp remained structure - free since construction activities were suddenly interrupted.The understanding of the original function of the building with the apse at Musov was made possible by comparing it to the similar constructions uncovered in Anreppen and Markbreit, where analogical situations were identified as military baths [4. Within this interpretation, the well at Musov should have provided sufficient amount of water for the bath complex.

A task of digging up the well must have been very challenging, as the terrain around the well was at the level of $183 \mathrm{~m}$ above the sea, whilst a current water level is to be found at the level of $169.5 \mathrm{~m}$ above the sea. Furthermore, the well was excavated in a location with non - homogenous quaternary gravels and minimal layers of clay.During the archaeological excavation the well manifested itself in natural as a big circular feature with a dark fill of approximately $8 \mathrm{~m}$ in diameter. The funnel shaped wellhead was formed via natural processes after the feature was no longer in use. Starting at the depth of $5 \mathrm{~m}$, it was possible to identify the edges of quadratic shaft of well itself, with traces of various colours marking the original timber framing. The cleaned surfaces showed the ground plan of a well as quadratic with its sides collapsed inward.

The base level of the earthworks achieved by the Roman builders was at a depth of approximately $8 \mathrm{~m}$, of which the best observed are the last two metres, where the infill proper of the well shaft manifested itself. Sporadic evidence of wooden well facing was noted as well as the gravel infill in the spaces between the fringe and edges of untouched gravel layers. (Dimensions of the well: evidence of timber lining on the ground plan marked area $250-260 \mathrm{~cm} /$ measured across the ground plan/, total depth measured from the level of detection down to the base of the excavation performed by builders in the Roman era: approximately $8 \mathrm{~m}$.)

The feature in Musov belongs to a category of wells with timber lining. Such wells were customary in the territories of Roman military expansions (e.g. Anreppen [8]), however water pressure supply systems with lead pipes are also known from the military compounds outside Roman territories in the early principate, (Lahnau - Waldgirmes, $70 \mathrm{~km}$ from the Roman territory on the Rhine [3]). The wells produced by various methods (dug in solid material, with lining fashioned with stones, bricks, wooden blocks and with boarding made of discarded barrels) were common components of housing, both in legionary camps and in the Roman army auxiliary corps' camps [1].

\subsection{The Process of Well Construction in Musov: Our Illustrative Solution - Relevant Sources, Possible Ancient concepts, Discussion}

The situation recorded during the well excavation allows us with certain probability to: A/ select corresponding work materials, B/ determine how they were utilised, and $\mathrm{C} /$ assess techniques and technologies, which were applied by military architects in the Roman period at this site. Several basic facts can be used as a starting point for a following discussion. For determining appropriate materials and their processing these statements are significant: 1) Traces of timber lining recorded in in plan were of the same thickness, approximately $4 \mathrm{~cm} ; 2$ ) The same thickness was also discovered in the corners; this being the determining 
factor of the manner the initial construction elements were connected; 3) The length of the sides complements the recorded thickness of the used elements. This fact should have corresponded with appropriate wood materials ensuring adequate firmness for withstanding expected pressures, even in a wet environment when the well was in use.

\subsection{Discussion Concerning Material Furnishings of the Well Construction}

The original thickness of the timber lining before destruction process took place could have been somewhat larger, but the ascertained $4 \mathrm{~cm}$ are corresponding to two (Roman) inches $(1 \mathrm{inch}=1.85 \mathrm{~cm}, 2$ inches $=$ $3.7 \mathrm{~cm}$ ), which means that the original construction elements could have been conforming to a standard plank. We assume that these planks were manufactured with a saw. According to the ancient architect Vitruvius (second half of the first century BC), oak should be chosen for a construction in the wet environment. In the antiquity, oak wood was commonly available in Southern Moravian region. The manner of joining the structural elements can be deduced from the fact that there are no traces of any reinforcements in the corners: individual components had to be joined without any overlap.

\subsection{Initial Information for Assessing the Shaft Construction Process}

Several facts are significant to understand the process of excavation and consequent activities, which were pertinent to insertion of timber lining into the well shaft. 1) The gravel that formed the terrace was very loose and did not allow excavating large sections of the construction pit - the work would have been threatened by uncontrollable destructions and collapses of the walls. 2) There was no success in establishing evidence for any obvious traces of makeshift support systems, which would point to evidence that the excavation proper was secured temporarily and that the military architects would have expected that when reaching the lowest point of the well, they would have constructed the final timber lining from the bottom of the shaft.No traces of vertical construction elements are available - beams that support the timbers; evidence is also lacking for existence of beams forming a supra structure which would enhance the solidity of the construction.

Thus, the excavation and the timber lining had to be done in individual stages. The shaft was always dug out by an established depth and boarding sections of beforehand determined length were put in place; the

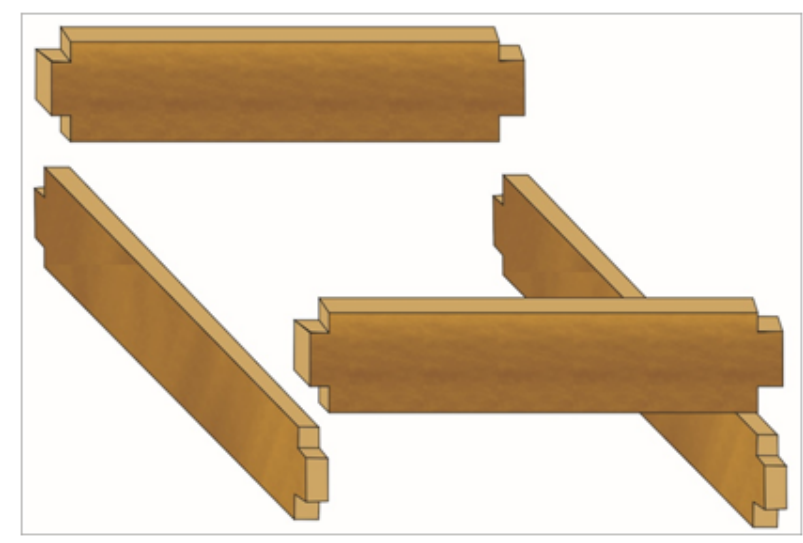

Fig. 3: Modifications of the planks used for constructing the well timbering

new elements fitted to the previously finished section. At the same time, filling of the hollow spaces between the timbers and the edge of the excavation shaft had to be carried out.

\subsection{Suggestions for Recognising the Circumstances Which Are Known from other Sites with Roman Well Construction}

Studying the analogies from other Roman provinces is problematic, since the archaeological recordings (drawings and photos) usually do not allow for a detailed recognition of wooden elements employed in the well constructions. N. Albrecht [1] in his doctoral thesis states that when the wooden wells of the so called "Kastenbrunnen" type from Roman provinces are studied, it is possible to find up to 14 specialist terms in relevant literature that are used to define joints of the wooden elements. Details recognised in the well from Musov correspond directly with techniques of joining the structural elements as "simple scarf joint or lap, dovetail joint, modular construction, rabbets" [1] (Abb. 13-15, 17) and similar solutions are possible [6], (Abb. 245).

The basic construction elements, the planks, appear in the category "Kastenbrunnen" in a schematic drawing [1], (Abb. 15) showing boards fashioned with a tenon in the middle of the short side, with chisel cuts on the sides. (The corresponding drawing reconstructions of N. Albrecht are erroneous and can be only as a subjective model - the connecting elements cannot be equipped with two tenons on the sides and a chisel cut in the middle. It would not be possible to interlock the next row of wooden planks with the existing structure.)

This version, with corrected dimensions, is presumed to be the correct one for Musov (fig. 3). The connec- 


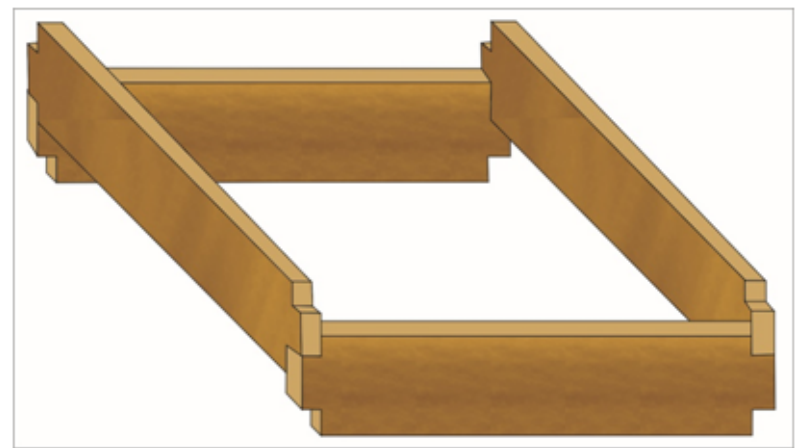

Fig. 4: Schematic drawing of interconnection of the planks example for the well in Musov

tions would be appropriate with joints applying joiner technology, so called "corner overstripped connection to the tenon and two chisel cuts on sides without overlapping". The planks were put together on the spot always in pairs - the left and the right one in the first step, and the front and the rear one in the following step (fig. 4). The elements ensuring a proper connection at the ends would be modified with a saw, for the sake of accuracy.Carpentry and joints made with an axe would not be suitable for the consequent construction process.

\section{Well Construction Work - Example}

The upper levels of the well were destroyed. We can only observe the construction process at the penultimate level, and in more details at the lowest level of the well construction, where the last work chamber was situated. The initial level of excavation for this chamber can be assessed at a level corresponding with level 6 (fig. 5). Up to this level the timber lining in the well shaft was put together and excavation of the shaft could start up to the base reached during the course of the well deepening - found approximately $2 \mathrm{~m}$ lower, at level 8.

In the initial phase, the material was excavated from the lowest level of the well shaft - a "room" with a square ground plan with rounded corners was formed, and the walls in the section were vaulted in the middle of the highest point (for the sake of distribution of lateral pressures).

After reaching the newly selected base of the well (at the level 8), a frame/wooden wreath made of thicker beams was laid in place. Its adjustment was performed according to the previously installed timber lining. The workers put planks in pairs onto the existing wreath, to begin with the front and the rear one, then the right and the left one, into their corresponding tenons.
As the boarding grew, immediate filling and follow up compacting of material put into the space between newly constructed timber lining and edges of the excavation was performed - thus the construction was protected against shifts and detachment of great blocks of mass from surrounding walls.

The timber lining was advanced closely to the existing construction of the previous, already completed, sections. Underneath the beams of the frame/wreath were laid the front ends of the stakes, which served as levers, and by the means of the combined pressure in the perimeter the newly constructed block was elevated so that it would rest on the existing structure. The lowest level of the planks was provisionally supported. It is probable that pins inserted into the peripheral walls of the pit were used, as well as slanted temporary struts supporting the lower edges of the planks the struts were intended to be gradually exchanged for longer ones during additional excavation of the base, and during lowering of the well itself. But additional construction activities did not occur:If our connection between camp area with a well and military expedition in $\mathrm{AD} 6$ is correct, then Tiberius as the supreme commander of the Roman forces ceased any ongoing construction work in the camp at Musov.

\subsection{Discussion Concerning Example Solution of Building the Well}

Corresponding material traces for verification of the suggested example solution, traces which were recorded in the field documentation, were in fact found only during preparation of this text. The completed timber lining can be traced from level 5 on, in the shape of a vertically positioned layer of extraordinary colouring, which is an indication of previous wooden construction elements. The well backfill and the gravel material in the spaces between planks and the edges of the excavation could be distinguished only at the lowest level (fig. 5). An extraordinary manipulation space can be seen in the section at the base of the lowest level. Here on the right, and especially on the left, there are the quadratic profiles that correspond with the beams of the frame/wreath excavated near the original level, where the levers were employed to ensure the correct setting of the new part onto the previous section. So the better preserved evidence with the quadratic section and dimensions of $8 \times 22 \mathrm{~cm}$ can be added to the construction elements utilised in Musov. (If we wanted to establish whether the measurements correspond with other Roman finds, it is possible to offer the fact that the beams should have had the dimensions of $1 \times 3$ palmi $(1$ palmus $=7.41 \mathrm{~cm}, 3$ palmi $=22.23 \mathrm{~cm}$, corresponding to $3 / 4$ of the Roman feet), although this offered explanation is not entirely satisfactory. 


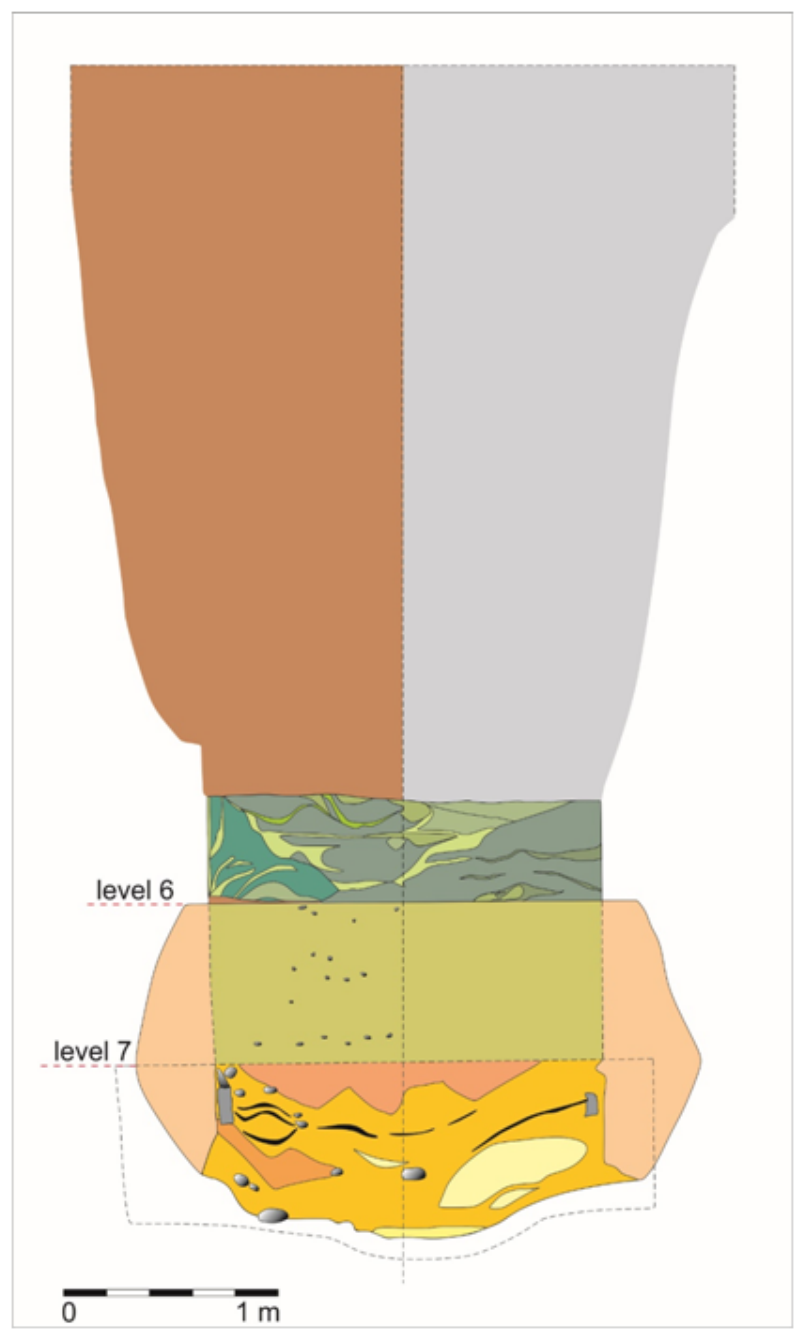

Fig. 5: Section of the crosscut of the well with lowest levels of excavation.

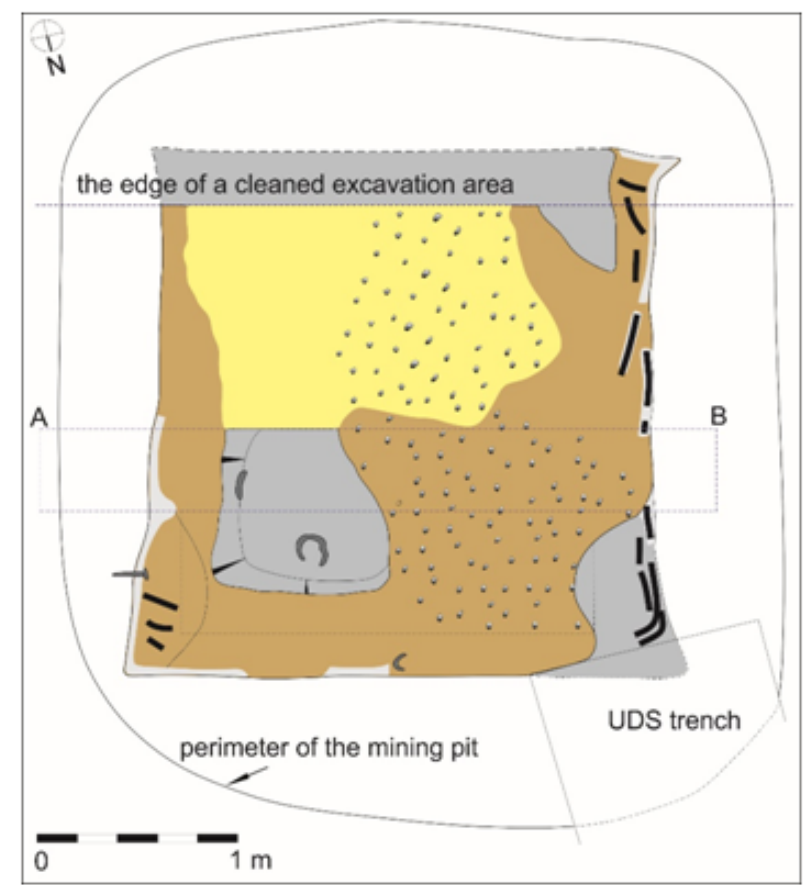

Fig. 6: The ground plan of the lower part of the well with evidence of timbering. A nail piercing the gravel layer is visible on the left side of the ground plan.)

It is interesting to note that an element related to supports of the lower parts of the timber lining was discovered. A large iron nail (length of approximately $12 \mathrm{~cm}$ ), which was driven through the timber lining and reached the backfill material behind the boarding, was discovered during the archaeological excavations. The presented example solution provides evidence for an explanation of its function: it acted as means of support for the lower sections of the completed timber lining and, together with the other wooden elements of construction, provided an obstacle against the possibility of the lowest planks collapsing, after the expected, but not realised, excavation would have occurred.

Confirmation for presumption of timber lining constructed of successively added elements is provided by the fact that at the start of the well construction, the well head was situated in concordance with the neighbouring walls of the building with the apse. In the depth of the well, where the timber lining manifested its role, it was geodetically recorded that its position was somewhat half-turned against the intended orientation. In the case of lowering the wreath or casing manufactured from vertical beams from the upper parts of the timber lining, such a mistake should have not occurred: new elements would have fitted the previously inserted ones, and would have linked up with them. Existing structural lines would, in such case, extend following the intention of the base of the initially laid construction. On the other hand, in the end when new parts of timber lining were forced in place some 
minor mistakes, such as the recorded half - turn, could not be excluded.

A question remains to what extent the chosen construction procedures could withstand the accumulated pressures; pressures which would affect the structure after the work was completed and the well would be in full use. Another problem is whether the dimensions of the planks and their thickness with their given length could prevent partial destruction of the walls or the total collapse of the structure. However, the selected construction procedure was obviously considered sufficient, although it is possible that the primary plans prepared in Roman controlled territory did not have to take into consideration the specific geological situation of a particular location.

\subsection{Intended Dimensions of the Well, Planned and Actual Completed Work Activities}

Complete ground plans are not available for the lower levels of the well. Moreover, pressures affecting unsettled fill of the well shaft caused marked vaulting of the walls. Dimensions in the middle of the sides fluctuate in various levels (oscillation of the lengths between 250 and $260 \mathrm{~cm}$ ). In the level presented in the drawing (fig. 6), after straightening the sides it is possible to ascertain that the longest one should be $282 \mathrm{~cm}$ long (corresponding to 9, 5 Roman feet) and the others are close to $266 \mathrm{~cm}$ long (8, 9 Roman feet). It is possible to suppose that the original length of the sides was slightly longer, and highly probably corresponded to the Roman 10 feet $(296 \mathrm{~cm})$. This means that the planks, the basic structural elements, were all of the same length.

The exact level where the well head was situated during construction is not known. It is probable that it was located $8 \mathrm{~m}$ above the known bottom level of the excavation. In the case that the planks used for the timber lining were for an example half a foot $(14.8 \mathrm{~cm}$, which is a width accommodating milling the lumber from smaller diameter logs) then one side of the timber lining would have been composed of 54 pieces and for timber lining the entire height of the well, 216 planks would have been prepared. If the dimensions of the planks were $2.96 \times 148 \times 0.04 \mathrm{~m}$ (with volume of $0.01620896 \mathrm{~m}^{2}$ ), the timber lining would contain $3.5 \mathrm{~m}^{3}$ of lumber. Excavated materials from the shaft were of great quantity as well - volume of up to $70 \mathrm{~m}^{3}$ was lifted from the completed part of the well.

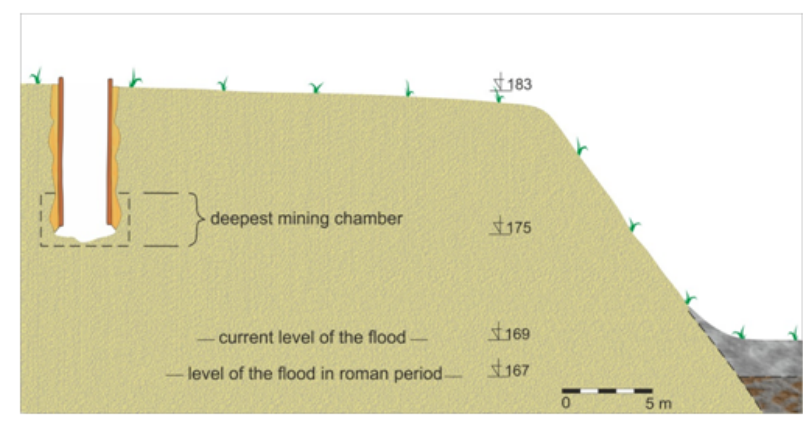

Fig. 7: Schematic representation of Roman well in the time, when the construction works were suddently breaked off.

\section{The Function of the Well According to the Original Project, Conclusion}

The width of the well shaft is surprising. In the given geological conditions the construction would be surely better executed if the planks could have been shorter. The dimensions of the well (the timber lining determined the space of $2.88 \times 2.88 \mathrm{~m}=$ area of $8.3 \mathrm{~m}^{2}$ ) depended on the needs to pump huge quantities of water continously; therefore, it was necessary to have a space for simultaneous drawing of many pails, be it manually or with aid of several windlasses or pulleys. The baths in the neighbouring building could not function without a vast supply of water.

If the construction of the well was not interrupted, the lowest level would have reached beneath the ground water table present in the Roman period. The current considerations 7] were based on data taken from the height of the water levels in the periods of flooding in the subrecent era, when the areas next to the foot of the terrace of the elevation of approximately $169 \mathrm{~m}$ above sea level were flooded. According to the information gathered from the excavations in the surrounding area, it is evident that two thousand years ago the ground level was at least $2 \mathrm{~m}$ lower, and it might have been possible to reach even deeper levels where ground water was accessible (fig. 7). It is highly probable that if the project of the well had been completed, the base level of the well should have been situated up to $8 \mathrm{~m}$ lower than the level which was achieved during the unfinished, interrupted construction. In the case of a completed well the military architects would have had to produce 432 planks (14.8 cm wide), which represented $7 \mathrm{~m}^{3}$ of sawn lumber, and the entire volume of construction material for the completed well shaft would have been $140 \mathrm{~m}^{3}$. The assembled material could not have been stored in the camp area.It would have been necessary to store it outside the camp fortifications and bring it inside the camp only when needed. The amount of manpower and actual labour necessary for the construction of the 
well confirms the demanding targets that were set by the people participating in designing and building the military camp in Musov in the early years of the Common era.

\section{Acknowledgment}

The paper has been supported by the Program of Research Activities of the Institute of Archaeology of the Czech Academy of Sciences, Brno, v. v. i., for the years 2012-2017.

\section{References}

[1] ALBRECHT, N. Römerzeitliche Brunnen und Brunnenfunde im rechtsrheinischen Obergermanien und in Rätien.Inauguraldissertation zur Erlangung der Doktorwürde der Philosophischen Fakultät der Universität Heidelberg. Philosophische Fakultät, Institut für Klassische Archäologie. 2014,261 pp. DOI: 10.11588/heidok.00016484.

[2] BALEK, M. and O. SEDO. Das frühkaiserzeitliche Lager bei Mušov - Zeugnis eines augusteischen Feldzugs ins Marchgebiet. Germania. 1996, 74, iss. 1, pp. 399-414. ISSN 0016-8874.

[3] BECKER, A. and G. RASBACH. Der spätaugusteische Stützpunkt Lahnau-Waldgirmes. Vorbericht über die Grabungen 1996-1997. Germania. 1998, 76, pp. 673-692. ISBN 3-8053-2356-5, ISSN 0016-8874.

[4] BIDWELL, P. Timber bath in Augustan and Tiberian fortresses. In: InLimes XVIII. Porceedings of the XVIIIth International Congress of the Roman Frontier Studies held in Amman, Jordan (September 2000).Bd. I. BAR: S1084.Oxford, 2002, pp. 467-482. ISBN 9781841714653.

[5] GROH, S. and H. SEDLMAYER. Expeditiones Barbaricae, Forschungen zu den römischen Feldlagern von Engelhartstetten, Kollnbrunn und Ruhhof, Niederösterreich. Archäologische Forschungen in Niederösterreich. Krems, Landessammlungen Niederösterreich und DonauUniversität Krems, 2015, 2, pp. 239. ISBN 9783-902505-83-5.

[6] HUTHER, S. Der römische Weihebezirk von Osterburken III, Band 2 - Kompendium zum Holzbau. Forschungen und Berichte zur Vor- und Frühgerschichte in Baden - Württemberg 127. Darmstadt, Konrad Theiss Verlag 2014, pp. 306. ISBN 3806229732, 9783806229738.
[7] KOMOROCZY, B. K otazce existence rimskeho vojenskeho tábora na pocatku 1 . stoleti po Kr. u Musova (kat. uz. Pasohlavky, Jihomoravsky kraj). Kriticke poznamky z pohledu rímsko-provincialni archeologie. In: InArcheologie barbaru 2005. Sbornik prispevku z I. protohistoricke konference "Pozdne keltske, germanske a casne slovanske osidleni", Kounice, 20. - 22, zari 2005. Praha: Ustav archeologicke pamatkove pece strednich Cech, 2006, pp. 155-205. ISBN 80-86756-11-4.

[8] KÜHLBORN, J.S. Delbrück/Anreppen. In: L'architecture de la Gaule romaine. Les fortifications militaires. Paris - Bordeaux, 2006, pp. 261-263. ISBN-10 2-7351-1119-9, ISBN-13 978-2-7351-1119-0.

[9] TEJRAL, J. Reevaluated but stillenigmatic the Roman site at "Burgstall" (okr. Brnovenkov/CZ). In: InHonesta Missione. Festschrift für Barbara Pferdehirt. Monographien des RGZM, Band 100. Regensburg - Mainz : RömischGermanisches Zentralmuseum, 2014, pp. 221-248. ISBN-10: 3795429226, ISBN-13: 978-3795429225.

[10] TEJRAL, J. Musov. Reallexikon der Germanischen Altertumskunde. 2002, 20, pp. 425-433. ISBN 3-11-017164-3.

[11] File: Vienna Basin physical. png. Wikimedia Commons [online]. (c) $13: 33 \quad 15$ Nowember 2013 Wikimedia Commons [viewed 29. 8. 2017].Proceedings: https: //commons.wikimedia.org/wiki/File: Vienna_Basin_physical.png 